INTERNATIONAL JOURNAL OF

MULTIDISCIPLINARY STUDIES IN ARCHITECTURE

AND CULTURAL HERITAGE

\title{
Hidden Heritage of Alexandria, Egypt
}

\author{
Ahmed Motawea Hussein Shaikhon a, b, * \\ a PhD Candidate Heritage and Museum Studies, Helwan University, Egypt \\ b Archaeologist at the Egyptian Ministry of Antiquities, Egypt
}

\begin{abstract}
Alexandria is located on the Mediterranean coast at the western end of the Nile Delta. Founded by Alexander the Great in 331 $B C$. Over the next three centuries, it became a center for trade and science, and Alexandria was a major port on trade routes between East and West, which made it an attraction for foreigners to reside in the city, and Alexandria thus became almost the most important port on the shores of the Mediterranean and an important center for foreign trade and a multi-ethnic, multi-cultural and multi-ethnic residential residence And, of course, the Jews had an abundant share in a sedentary life in this atmosphere. Graves are one of great importance in Archaeology, as tombstones contain valuable information about religious texts, Promotional phrases, dates, decorative elements and symbols. It is truly an official document that records the history and civilization of each country, the most authentic representation in the era and history recorded on it, shedding light on many different aspects of life throughout the ages reflecting the economic situation of the deceased in particular and of the country in general, and in genealogy, kinship and conjugal relations It's credible and beyond doubt. Those who wrote them never imagined that they would ever be a historical source. Tombstones, whatever their religion, are an important source of the history. This paper sheds light on an ignored part of the cultural heritage of Alexandria, which are the cemeteries of Jews. Unfortunately, few studies dealt with the cemeteries of foreigner's in Alexandria .In addition, no research has been found that surveyed all the cemeteries in the city. The aims of the study was to conduct a detailed survey to gather all available information from the various sources about The cemetery of Jews in Alexandria, Egypt these sources are archaeological sites and literature to highlighting the importance of the various architectural styles of the tombs in this historical period With a study of some models of tombstones.

\begin{tabular}{ll}
\hline \multicolumn{2}{l}{ Keywords } \\
- & Cemetery \\
- & Hebrew \\
- & Heritage \\
- & Tombstones \\
$-\quad$ Jews \\
$-\quad$ Monumentality \\
\hline
\end{tabular}
\end{abstract}

\section{Introduction}

Jewish cemeteries have an important role to play in remembrance. In 
Hebrew, a burialground may be referred to by several names: Bet Kevarot 'house of graves', Bet Hayim 'houseof life' or Bet Olam 'house of eternity' (Kadish 2011: 59). As these names imply, the cemeterycarries many values and layers of significance, not least remembering the dead, an act which "carries moral implications for the behaviors of the person engaged in remembering' (Bar Levav 2002: 34). "Elamin" means the Hebrew word "eternal", which is the land of the cemeteryand the burial of Jews because death is considered one of the holiest of their people. The Jewswere one of the largest communities in the province of Alexandria, and Alexandria lies on theMediterranean coast at the western edge of the Nile Delta. It was founded by Alexander the Great in $331 \mathrm{BC}$ and over the next three centuries became a Centre of trade and scholarship. Alexandria was the capital of Egypt during the Graeco-Roman period and the first port and commercial center in Egypt since its building till present. By the Arab conquest, the importanceof the city decreased, but then, it retrieved its importance in the Fatimid and Ayyubid eras. The golden age of the city during medieval times was during the Mamluk era since the Mamluks controlled most of the international trade in the world and Alexandria was a major port on traderoutes between the East and West. Merchants preferred to live in Alexandria to supervise theirtrade; especially that the Mamluk sultans gave them privileges that encouraged and facilitatedtheir stay (al-Shayal, 2000). The Ottomans followed the steps of the Mamluks and welcomed foreign merchants to stay in Alexandria and pursue their business. Due to the important locationof the city it was the first target of the French occupation in 1798 and the British invasion in 1882 and from it the last king of Egypt was expelled after the revolution of 1952 (Ibrahim, 2013). It owns a wealth of tangible and intangible heritage that was formed throughout ages and by a variety of contributors. And The Jews were of Alexandria built their own tombs and carried 
their rituals where the burial was carried out in the direction of Jerusalem and tombstones written in the national language for them "Hebrew", so the tombs of Jews in Alexandria were built on the ancient Jewish architectural heritage, The tombs of the Jews whohad been living in the city since the second half of the nineteenth century. The tombs and synagogues of the Egyptian Jews that were built on the land of Egypt It did not find the right amount of studies, and did not find the appropriate research. This paper is a descriptive study that starts with a historic introduction about the Jews community in Alexandria and the Jewishburial mores as well as provides more information of the cemeteries in Alexandria with the details. Afterwards, the ignored heritage of Jews Cemeteries in Alexandria will be revealed and its importance will be proven, that is to concentrate on the methods of making use of it tobe known for everyone. Therefore, this paper aimed to uncover the history of Jews in Alexandria with describing the Jews cemeteries in the city. The conclusions highlighted the importance of raising the cultural heritage knowledge and awareness of the local community, in addition to the use of those heritage sites in flourishing the heritage tourism in Alexandria.

\section{The Jews Community in Egypt:}

The Jews of Egypt belonged to very different origins and cultures.On the religious level,there were "Rabbanite Jews" and "Jewish Karaites". The "Rabbinic Jews" base their religion on the written Law (Torah), the Oral Law (Talmud) and rabbi commentaries. Hence the nameof Rabbanites which distinguishes them from the Karaites, which take into consideration onlythe Torah. As for origins, there were Oriental Jews, Sephardim and Ashkenazim. In terms of civil status, there were three 
groups: Egyptian citizens (35\%), foreign citizens (25\%) and stateless people (40\%). Eastern Jews included natives and those from North Africa, the Near East, Iraq, Yemen) Manzoni, 2011). Finally the Ashkenazi, a community formed in the second half of the nineteenth century, included survivors of pogroms from Russia, Eastern Europe andrefugees from Nazism. Eastern Jews, of which the Caribbean was one, spoke Arabic. In addition to the language of the country of origin (e.g. Italian), some of the Sephardim spoke Ladino (Judeo-Spanish) and Ashkenazi, Yiddish. In the 20th century, French became the "lingua franca" common to almost all Jews in Egypt. Since the Jewish graves in the Alexandria are for the burial of the dead Jews, and the burial of books and sacred documents and writings that are no longer usable, known as the "Geniza", each of these types of burial has its own rituals. As for the sacred documents and writings that are not usable for "Geniza", they are collected in special places in each Synagogue, called temporary Giniza. After the fullness of that place, which is not filled manyyears ago, according to capacity, may be up to a thousand years, as was the case of the Ibn EzraSynagogue in Fustat, Egypt. The official of the Synagogue announce the date of transfer of the Giniza to the cemetery, sacred materials are filled in bags, and are brought to the tombs in a ceremonial funeral procession majestic. In the graves are recited their own ceremonies and thenburied in the caves of the "Geniza". Because The Jews believe that the Hebrew language is the language of the Lord, and therefore it is a sacred language whose written characters cannot be desecrated or insulted in any way. Therefore, materials containing Hebrew characters, whatever their quality, must be collected after they become unusable and buried in private graves. It will wear off in a manner of nature, as the body will wear after the burial. Jews for instance consider the dead to be impure, and this sense of impurity leads to the physical distancing of cemeteries from their 
associated communities (Bar Levav 2002: 18).

\section{Jewish Burial Mores:}

A central tenet of Judaism is that the body is a gift of God - indeed, that it belongs to God (Lamm 1999: 242). This belief structures the careful consideration given to the dead in Judaism, with halakhah (Jewish law) requiring that, whenever possible, burial takes place within 24 hours after death. Two important steps precede the burial: 1. Taharah (purification)

- a ritual cleansing process in which the body is cleaned and groomed, and water ritually pouredover it. 2. Levayah (the funeral) - friends and family accompany the body to its resting place in a show of respect for the deceased.

According to halakhah, a Jew should be buried among Jews, with the body in its entiretyreturned to the earth in a way that allows for natural decomposition to occur. Although Jews do not place great emphasis on the afterlife, the eventual Resurrection of the Dead is a basic doctrine of the faith. As a consequence, the integrity of the body must be respected and preserved throughout the burial process, with strict rules against embalming, display, autopsy or cremation.

Jewish law also has strict dictates with regards the mourning process and subsequent remembrance of the dead. There are a stages to mourning: pre-burial mourning, Shiva,Shloshim and Yahrzeit

The sanctity of the burial is an important aspect of the Jewish faith. It takes various forms according to the cultural, historical and national environment in which the various Jewishcommunities live. In general, the Jews are careful to wash their dead as quickly as possible, then they bury them in the celebration must be 
characterized by simplicity after prayers recitedKaddish.

The Ashkenazim use coffins where the dead are buried, and the Oriental Jews bury theirdead on the ground, as is the case with Muslims. The dead Jew is usually buried in the prayer shawl (Talit), which he used during his lifetime. Whoever kills is taken with his stained clothesand drains his body so as not to lose any part of his body. If the deceased is a child who has not circumcised, the Jews hold his circumcision before burial, in addition to the Hebrew name. One of the prayers of the Ashkenazim in the Jewish funeral included the request for forgivenessfrom the corpse, which usually existed until 1887, when it was stopped by the Chief Rabbi of England. Safard cast coins in the four quarters as gifts or bribes for evil spirits.

It is a characteristic ritual among the Jews of Libya that if the widow of the deceasedis pregnant they lift the coffin and the widow passes under it until it turns out that the dead is the father of the fetus that carries it. There is no doubt that many of these customs and rites arederived from the cultural traditions of the peoples who lived among them members of the Jewish communities, which explains the different burial habits among the Jews of Europe, forexample, and the Jews of the Arab countries or Africa, and Jewish burial sites receive the sameattention as the burial rituals, It is called the House of the Living or the Eternal House. One ofthe rabbis stated that the cemetery is more holy than the Jewish temple, meaning that the place where the Jew is buried is holier than the place where God worships.

\subsection{Shiva, Shloshim and Yahrzeit:}

Shiva means seven and is the period of mourning immediately following the burial. Tradition is that the day of burial counts as the first day of Shiva, and 
continues seven days. Although no public mourning is observed on Saturday, the Saturday's and Holidays count in the seven days. Shloshim, which means thirty in Hebrew, are the thirty days following the burial, with the day of the burial counting as the first day. Usually then, Shiva is the first sevendays of Shloshim. At the conclusion of Shiva, Shloshim serves as a period of re-entry into theworld of the living for the mourner. This is the time when the mourner returns to work or school, and begins to start living without their loved one. During Shloshim, the mourner traditionally avoids music, gaiety, and other forms of celebrations. The annual anniversary of the death of a person is called the Yarzheit and is traditionally observed based on the Hebrew calendar. The Yarzheit is observed by lighting a twenty-four hour candle the evening before the day of the Yarzheit and most people recite the Kaddish and take a few moments of introspection and thought.

The Jews visit the graves on holidays to perform the prayers before the graves of the dead until they are interceded with God. All Jews must be buried in the same place in the sameway, and special places are kept in the tombs for scholars, rabbis and prominent figures. To beburied in the Holy Land is a special sign, and this is logical in the contextual framework. With the advent of God in the earth and the people, and not exceeding them, individual immortalityretreats and is replaced by immortality through communion with the nation and the earth.

\subsection{Kaddish:}

" Kaddish" is an Aramaic word meaning "holy" and "kaddish", one of the most famous Jewish religious inscriptions written in Aramaic. It has been known since the time ofthe Second Temple, as it was recited before and after the prayer 
or before and after reading the Torah. However, it did not acquire its present form until the 8th and 9th centuries. The Kaddish praises the final glorification of the name of God and His kingdom and submission to His rule and His will and expression of hope. The speed of the coming of the scissors. TheKaddish has been developed and introduced several additions, which forms the concluding part of the Jewish prayer (shmaa, supplications, Kaddish). There have been many supplications called "Kaddish", and there are four basic types:

1. Short Kaddish (or semi-Kaddish) is recited before or after certain parts of the prayer.

2. The full Kaddish is the concluding part of the Jewish prayer.

3. Rabbinic Kaddish is recited after completing the lesson.

4. Kaddish mourning and recited by relatives of the dead, has become the most importantspecies after Kaddish prayer.

When the Kaddish is recited as a prayer of mourning for the dead, it is the son of the dead who recites the recitation. If there is no son, Rashid is mentioned by the family or any volunteer Jew and continues to recite Kaddish for eleven months and one day from the date ofdeath. The reason for the length of this period is the belief of the Jews that the punishment of the sinners in hell lasts for a whole year. Therefore, the Kaddish recitation should be stopped before the end of the year so that the deceased does not appear to be one of the sinners, and theKaddish is also recited on the anniversary. Of the types of intercession and magic formula thatcan influence the divine will, and there is a Jewish legend that Rabbi Aqiba received the forgiveness of a man where his son learned how to read Kaddish mourning on the spirit of hisfather. At present, the Reform and Conservative Synagogue allow women to read Kaddish, perhaps because of the Christian influence around them (where 
women light candles to commemorate the dead). There is a tradition of visiting graves before the Jewish New Year toask the deceased to intervene for the living before Yom Kippur, the Day of Judgment, which falls ten days after the New Year.

\section{Alexandria Jews Cemeteries:}

The Jewish cemeteries in Alexandria represent an open-air museum whose visitors draw cultural information about the lives of the Jews of in Alexandria, unparalleled in the worldand in no other sources. The Jews were one of the largest communities residing in Alexandria,and they built their own burials and carried their rituals where burial was taking place in the direction of Jerusalem and tombstones written in their national language, "Hebrew", so the tombs of the Jews in Alexandria were built on the ancient Jewish architectural heritage, which includes three cemeteries belonging to the Jews who have been residing in the city since the second half of the nineteenth century, where the official archives of the Jewish community in Alexandria record the first cemetery in 1836 while the last was in 1954.

three different locations in Alexandria have Jews memorial cemeteries the first one islarge cemetery, which is located in Khartoum Square in the Azarita area of the Latin Quarter,area Latin neighborhood, and the second cemetery is located in the area chatby, and the thirdcemetery is located in Al Shalalat Gardens in the section Bab Sharq. Referring to this cemetery,Botti (1898) in his book "Plan de la ville d'Alexandrie à l'époque Ptolemaique" mentions thatthe Sultans gave this region to the Jews for being a cemetery. The name "Sultan" was usedbefore Mohamed Ali and that means that this cemetery was there earlier than the 18th century.Also, Botti (p.137) mentions that the Jews of Middle-ages, used to take the blocks of the ancienttheater's foundation, in order to make funeral monuments. The 
official archives of the JewishCommunity of Alexandria records the first burial in 1836 while the last one took place in 1954; but from the previous information, it seems obviously that the area was used as a Jewishcemetery much earlier. The oldest tombstone recorded on the date of death, located in theChatby cemetery dating back to $1841 \mathrm{AD}$. The next lines explain all those cemeteries in detail.The three Jewish cemeteries in Alexandria are No. 1, the oldest, is located in Khartoum Square, Azarita District, and Latin Quarter. No. 2 (Menasce cemetery) and no 3 (dedicated in1908) are located in Chatby, and overlook the tram line. These three cemeteries remain today(2020) the most "living" testimony of the presence of the

Jews during the modern period. Theancient Jewish cemetery in Alexandria is the second largest Jewish cemetery complex in Egypt,and the first in "Basateen", Cairo

is the largest. It is also one of the most important memorialcomplexes in the world. It represents the eternal proof of coexistence between different religions under different rules, and a sign of mutual respect and tolerance.

\subsection{Azarita Cemetery:}

The old Jewish cemetery in Azarita is one such cemeteries built in Alexandria in the area of Khartoum Square in Azarita district, located in the Latin Quarter, on an area of five acres and surrounded by a high wall of iron, dating back to the second half of the nineteenth century. The tombs of the first Jews include about twenty thousand tombs above each grave, asign bearing the name of the deceased, and below them David Star, which are typical tombs ofform and design. They are designed on the simple Jewish architectural heritage and are completely devoid of precious decoration because they were tombs dedicated to the poor. Andthe simplest of the Jewish community in Alexandria at the time, and one of the most famous figures 
buried in those graves is the tomb of the Jewish Rabbi "Nathan" and closed those graves by burying the last body in 1956. Its variety of gravestone languages, inscriptions, and most of all symbols offer endless opportunities for study. The Jewish cemetery in Azarita has very detailed gravestone that reveal much about the people's lives, including decorative patterns andsymbols on the gravestones, as well as representations of professions and ways that people died.

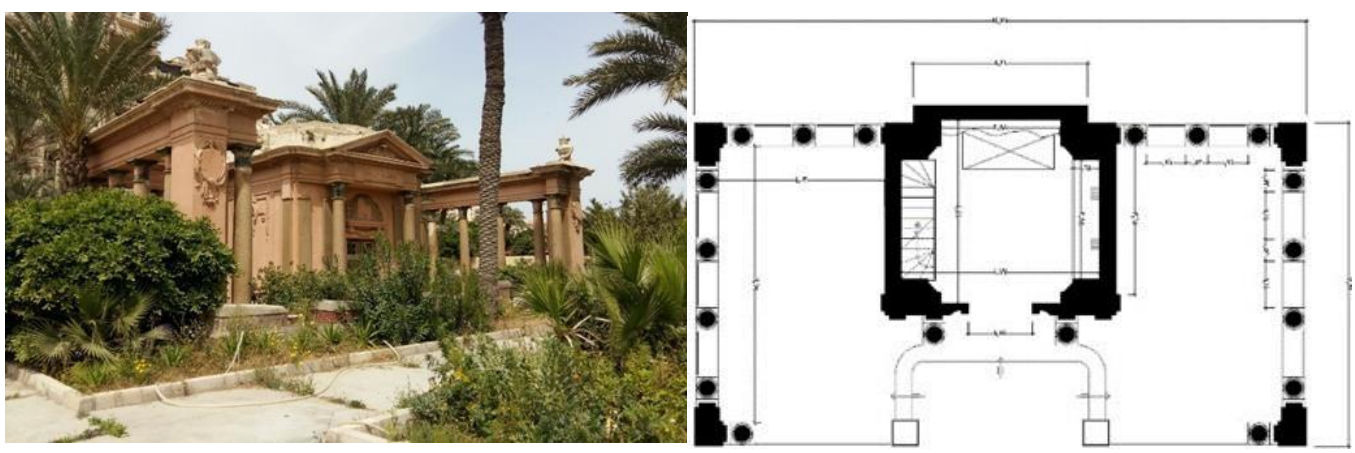

Fig. 1 - Suares Family Mausoleum.

There are over thousands of tombstones, numerous findings indicate great differences between the gravestones, as a consequence of different characteristics of the deceased, which actually caused a desire to indicate diversification of the gravestones through the detailed shapes, ornaments or epitaphs. In this cemetery, there are only five French burials of WWI, which were donated by the chief rabbinate of Alexandria. One of the graves was for an aspiringdoctor who died from his injuries after the battles of 11 November 1918. Another grave was for Marcel Erlanger who died on 14 July 1920, and his family demanded the return of his bodyto France. 


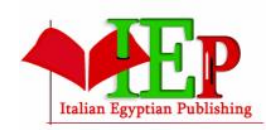

ISSN: $2735-4415$

\subsection{El Chatby I cemetery "Menasce cemetery":}

The second Jews cemetery located on Chatby a district on the eastern side of the city ofAlexandria, known as Al Horaya Square. The cemetery is located within the main Alexandriaforeigners Cemeteries complex, which is bordered by Al Horaya Square on the south way andthe electric tramway. The cemetery is enclosed by walls and entered through a metal gates secured archway, divided into plots, organized in rows.

The monuments of this graveyard can be divided into several types according to the style, forms, and certain symbols: laid monolithic slabs and coffins, with or without epitaph; monolithic ridges and compositing (empty) sarcophagi; as well as different modalities of coffins and sarcophagi that at the upper side end in: flat shape, round, round step-like shape, ridge, or with distinctive reduction in height and width, starting from the front towards the backside of the monument.
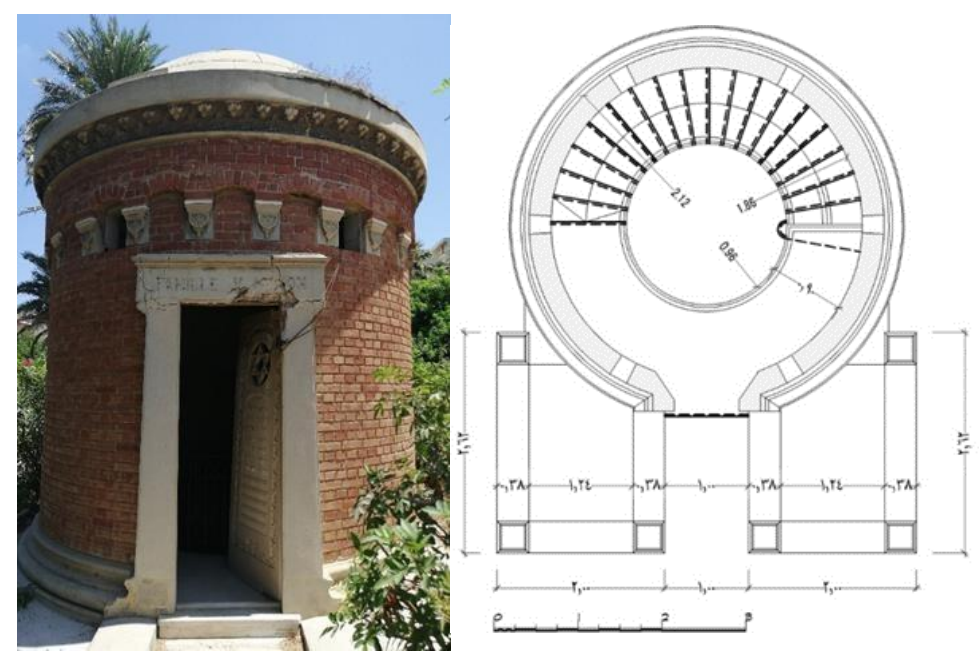

Fig. 2 - Aghion Family Tomb, 1915. 


\subsection{Cemetery Chapel:}

The chapel is located on the northwestern side of the cemetery. It was built between 1923 and 1924. It is a rectangular building with a central façade and the outside dimensions of the chapel are $9 \mathrm{~m} . \times 15 \mathrm{~m}$. A prominent entrance and the opening of the entrance is a pointed Gothic arch that adorns from inside of fish scales Ornament as a background to the Jewish candlestick shape below the Menorah symbol written in Hebrew. The main purpose of the church is to purify the body, perform prayers, and celebrate before the burial.

The mortuary (Hevra Kadisha) often served as a ceremonial hall where the bereaved gathered before the burial. It was sometimes used as a shed for the funeral coach. It also housedother facilities needed for the maintenance of the cemetery.
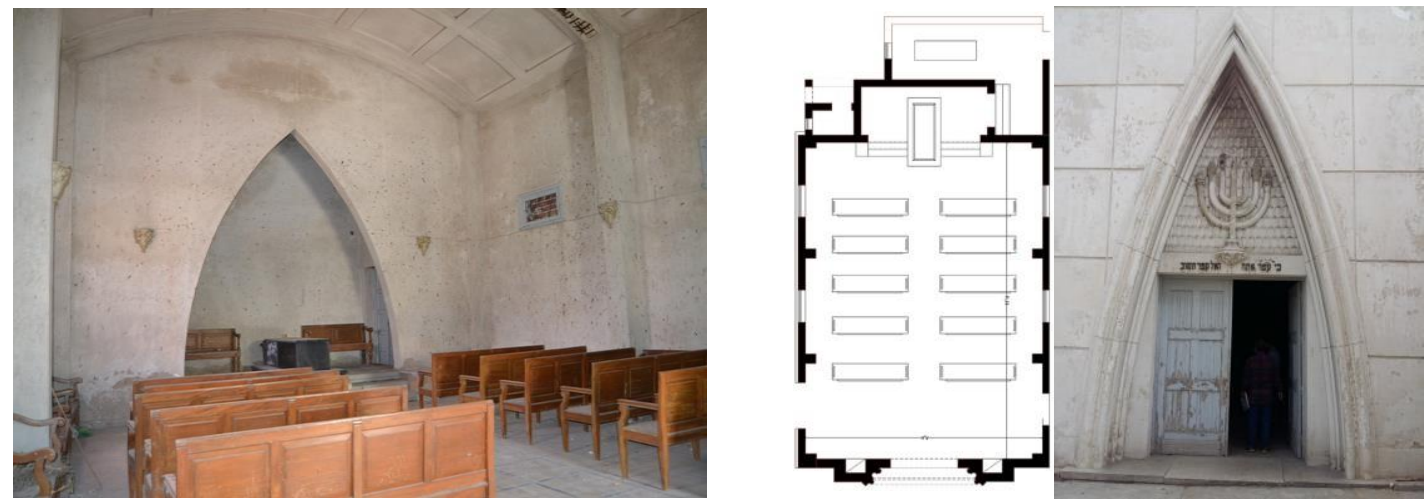

Fig. 3 - (a) Cemetery Chapel; (b) plan; (c) Entrance 


\subsection{El Chatby III cemetery:}

the third tombs of the Jews of Alexandria and the last one, which is located at the easternend of Abdel-Hamid Abo-Heaf Street, next to the tombs of the Copts in front of Bab Sharq police station. A large area with high walls, designed in the modern architectural style, and built with a system of combined animals; tombs built with white marble inscribed with Hebrewengravings. A great sarcophagus and it is just a solid carved block and the person is buried under or in front of them. This cemetery is one of the Jewish civil cemeteries in Alexandria. Itcontains twenty burials of WWI, all of them together in one plot, except a memorial to a man of the Zion Mule Corps. In the center of the plot, there is an Ionic column on a high square base and around it the headstones similar to those of the Commonwealth cemetery but with theDavid Star instead of the cross.

\section{Tomb Stones:}

Tombstone on the territory of Alexandria has extremely important historical documentary and artistic value. It provides numerous information on the deceased, such as gender and social status. Time of creation and regional characteristics, as well as numerous other direct information, can be determined according to the material used and the shape, whereas informative graphics of epitaphs is a proof of spirituality of that period. That is why the Shape solution for each monument is 
special. It represents specific characteristics of the deceased, with additional characteristics of the region. Graves built without megalomaniacal pretensions indicate differences, precisely emphasizing the qualities of the deceased person as well as other information, which gives them important documentary value. Through their developed shapes and symbols, these monuments have documented many facts about the time of their origin, spiritual achievements of the environment, and especially about the person buried. Therefore, each monument represents a special project.

There is a history being communicated to the viewer. If we consider that gravestones and death monuments act as material tools that communicate cultural information, the cemeteryin Alexandria presents images that illustrate values of the religious community (Hands of Blessing, Tree of Life) and also personal symbols (Ships, Death scenes). While epitaphs offerdirect personal information such as birth dates and death dates, language barriers can restrict their communicative quality; these barriers can be both the requirement of knowledge of the language, and also the limits of written language at conveying emotion in the same ways as images (Kaitlin Wilson p. 24). 


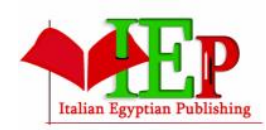

ISSN: $2735-4415$

\section{INTERNATIONAL JOURNAL OF \\ MULTIDISCIPLINARY STUDIES IN ARCHITECTURE \\ AND CULTURAL HERITAGE}

VOLUME 3, ISSUE 1, 2020, $135-154$.

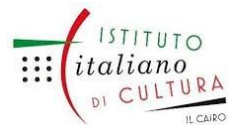

www.egyptfuture.org/ojs/
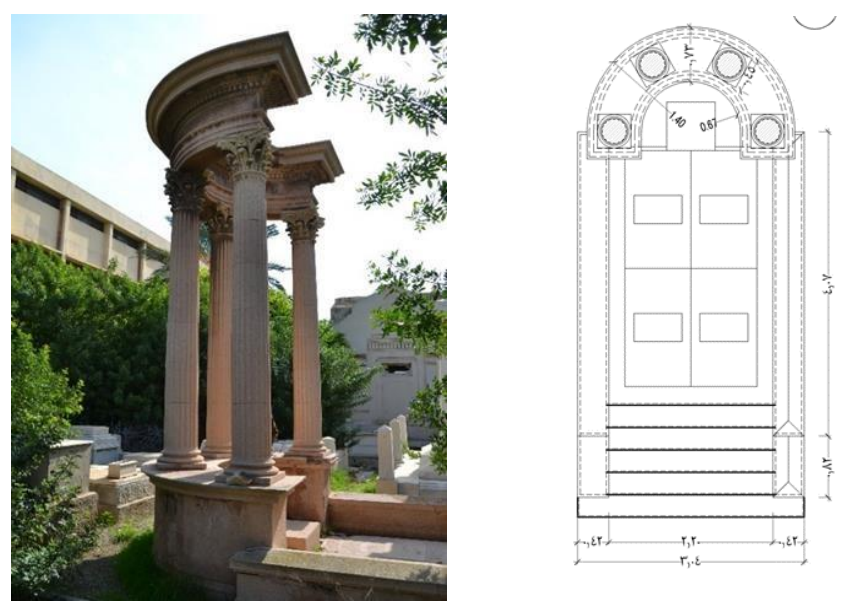

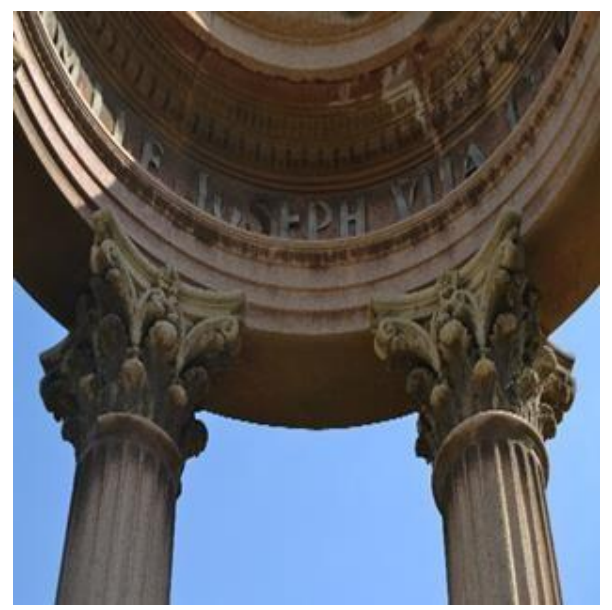

Fig. 4 - Joseph Vita Levy Tomb, 1939.

The Jewish cemetery in Chatby contains a very detailed tomb that reveals much aboutpeople's lives, including decorative patterns and symbols on tombstones, as well as representations of the careers and ways in which people died. There are more than thousands of tombstones; many results indicate that there are significant differences between the tombstones, as a result of the various characteristics of the deceased, which actually caused the desire to indicate the diversification of the tombstones through detailed shapes, ornaments or inscriptions.

In Alexandria, the common factor behind the gravestones in the Azarita cemetery is 150 
they were all members of the Jewish community in Alexandria. Symbolic differences betweenthe tombstones in Chatby's tombs can be understood as being influenced by history, historical factors, individual design preferences, and also whether an individual or families are able to pay more for a detailed tombstone. Jewish burial lands are an important feature of our national cultural heritage, but they remain largely closed spaces, literally and symbolically, with manyenclosed spaces and only accessible to rest ceremonies, or by prior arrangement. The main characteristic of those sites is the variety in the nationalities of the buried. Jewish burial grounds represent a significant feature of our national cultural heritage. This isolation carries benefits and drawbacks, not least around the vandalism such seclusion protects against or makes possible. As these communities shifted and migrated across the country, their associated burialgrounds were often left with no local faith-based presence to care for them. This has led to thesites that can seem abandoned and neglected because the communities that established them no longer represent a significant presence in the local area.

\section{CONCULSION:}

It can be concluded that Alexandria has three sites of Jews cemeteries. The sites are ignored and out of any kind of cultural activity or use from the tourism sector. The main characteristic of those sites is the variety in the nationalities of the buried. Jewish burial groundsrepresent a significant feature of our national cultural heritage, but they remain largely closed spaces, literally and symbolically, with many locked and only accessible for interment ceremonies, or by prior arrangement. This isolation carries benefits and drawbacks, not least around the vandalism such seclusion protects against, or makes possible. As these communities shifted and 
migrated across the country, their associated burial grounds were often left with no local faith-based presence to care for them. This has led to the sites that can seem abandoned and neglected because the communities that established them no longer represent a significantpresence in the local area. In light of that, it is the right time to spread the awareness betweenthe local communities. In addition, the stakeholders of the tourism sector could make use of these sites in flourishing the culture and heritage tourism in Alexandria. It is positive that Egyptian Ministry of Antiquities has started register Jews cemeteries as antiquities in 2018. Infact, the Jews memorial cemeteries in Alexandria have a great historical importance and represent an essential part of the preserved heritage of Alexandria. In order to reveal these cemeteries to be known, they can be placed as a new destination for the heritage tourism in Alexandria that can play an important role in raising the cultural heritage knowledge and awareness of the local community.

\section{Biography:}

Ahmed Shaikhon, PhD Candidate in Heritage and museum studies, Helwan University, Egypt, graduated from Faculty of Archaeology Sohag University, Holding an MA in Culture Heritage Management from Paris1 Sorbonne University in 2015 and works as an archaeologist at the esteemed Egyptian Ministry of Antiquities Since 2008.

\section{References:}

- Arafa Abdu Ali, 1993: The file of the Jews in modern Egypt, Cairo.

- Arafa Abdu Ali, 2000: the Jews of Egypt since the era of the Pharaohs until 2000, the Egyptian General BookOrganization, Cairo.

- Association for Gravestone Studies, https://www.gravestonestudies.org. 


\section{INTERNATIONAL JOURNAL OF \\ MULTIDISCIPLINARY STUDIES IN ARCHITECTURE}

AND CULTURAL HERITAGE

- Botti G., 1898:"Plan de la ville d'Alexandrie à l'époque Ptolemaique" Alexandrie.

- Caplan, Judith Shulamit Langer-Surnamer. "Tombstone Translation Topics: How to Decipher and Read a Hebrew Tombstone". In: $19^{\text {th }}$ Annual Conference on Jewish Genealogy: Syllabus. (New York: Jewish Genealogical Society, 1999), pp. 217-221.

- Cohen, Mark ,1987: Jewish life in Medieval Egypt, 641-1382, Tel-Aviv University, p. 91.

- DOROT, The Journal of the Jewish Genealogical Society (New York:

- G. al-Din al-Shayal, The History of Alexandria during the Islamic Era, Cairo: Dar al-Maaref, 2000, pp. 39-51;55-84.

- Goitein (1967-1988): A Mediterranean Society "The Jewish Communities of the Arab World as Portrayed inthe Documents Of the Cairo Geniza", Berkely University of California Press, pp. 10$13 ; 20 ; 24$.

- Gudrun Kramer B. I. Co. and Tauris. Ltd. The Jews in modern Egypt 1914-1952 London. No. 4 on publication1989, Near East, University of Washington.

- Jewish Encyclopedia, the Jews in Egypt, 4 Vol, p. 381.

- Kaitlin Wilson,Symbols and Place: A Study of the Gravestones at the Historic Jewish Cemetery in Curaçao,University of South Florida,2009.p. 15.

- Krajewska, Monika. A Tribe of Stones: Jewish Cemeteries in Poland. (Warsaw: Polish Scientific Publishers,1993). 242 pages. \{Mostly illustrations\}. OCLC 925571139.

- Kurzweil, Arthur. From Generation to Generation: How to Trace Your Jewish Genealogy and Personal History.(New York: HarperCollins, 1994). Chapter 9, pp. 342-358.

- Laila Ibrahim Abul-Magd,1987: Jewish Documents in Egypt in the Middle Ages (Cairo University), A Non-Dissertated PhD Thesis, Faculty of Arts, Ain Shams University, 1987, p. 11.

- Mahmoud Mohamed Soliman, 1996: Foreigners in Egypt: A Study in Egypt's Social History, Ain for Humanand Social Studies and Research, Cairo.

- Muhammad Khalifa, Al-Nabawi Siraj,1999: The Geniza and the Jewish Opponents in Egypt, No. 9, theOriental Studies Center, Cairo University, 1999.

- N. Ibrahim, Alexandria during Ottoman Era: Economic and Social Life, Cairo: Egyptian General BookAuthority, 2013, pp. 245-267. 
INTERNATIONAL JOURNAL OF

MULTIDISCIPLINARY STUDIES IN ARCHITECTURE

AND CULTURAL HERITAGE

- Obadiah Jara Da Bertinoro, 1930: Itinerary of Obadiah 1487-1490, A.D., in Jewish Travellers, edition. ElkanNathan Adler, London, pp. 143.

- Qassem Abdu Qassem, 1993: Jews in Egypt, Dar al-Shorouk, Cairo.

- Rath, Gideon. "Hebrew Tombstone Inscriptions and Dates", in Chronicles (Newsletter of the JewishGenealogical Society of Philadelphia), Vol. 5, No. 1 (Spring 1986), pp. 1-4.

- Robert Dassa, 2003: (Return to Alexandria) Raya Center, Cairo.

- Robert Ilbert and Illio Yannakakis, 1992: Alexandria 1860 - 1960. The life of a cosmopolitan Bafra. SocietyAlexandria, Egypt.

- Said Abdul Salam Al-Akash, Gahlan Ismail Muhammad: Pictures of the Life of Jews in Egypt in the Light ofthe New Geniza Documents, First Edition, Cairo, 2011, p. 165.

- Sandro Manzoni, 2011 the Jews of Alexandria, Amical Alexandria Yesterday and Today, Switzerland p. 3.

- Schafer, Louis S. Tombstones of Your Ancestors. (Bowie, MD: Heritage Books, 1991, 2007). 160 pages, paperback. \{Doesn't deal specifically with Jewish tombstones\}.

- Schwartzman, Arnold. Graven images: Graphic Motifs of the Jewish Gravestone. (New York: H.N. Abrams,1993). 144 pages. OCLC 891405959.

- Strangstad, Lynette. A Graveyard Preservation Primer. (Nashville, Tenn.: Association for Gravestone Studies,1988, 1995, 2013). 126 pages. OCLC 1007570142.

- Wright, William, 1890: Lectures on the Comparative grammar of Semitic Language, Cambridge, p.137.

Received: February 15, 2018

Accepted: April 20, 2018 